Article

\title{
Sustainability in the University: A Study of Its Presence in Curricula, Teachers and Students of Education
}

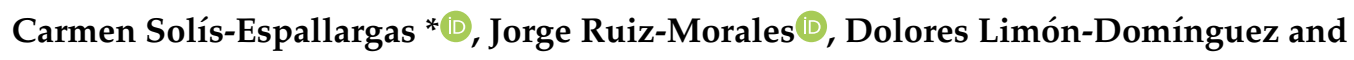 \\ Rocío Valderrama-Hernández \\ Faculty of Education, Universidad de Sevilla, 41013 Sevilla, Spain; jruiz2@us.es (J.R.-M.); dlimon@us.es (D.L.-D.); \\ rvalderrama@us.es (R.V.-H.) \\ * Correspondence: carmensolise@us.es; Tel.: +34-955-420-784
}

Received: 18 October 2019; Accepted: 22 November 2019; Published: 23 November 2019

check for updates

\begin{abstract}
This work forms part of the $\mathrm{R}+\mathrm{D}+\mathrm{i}$ 'Training project in Spanish universities for professionals as agents of change in order meet the challenges facing society' (Educación e Innovación Social para la Sostenibilidad (EDINSOST) 2017-2019). The purpose is to analyse the presence of sustainability in terms of curriculum content and training in competence for students, teachers and the curricula of Science of Education degree courses at the University of Seville. In this context, the curricula of the Degree in Early Childhood Education, Primary Education and Pedagogy have been analysed. Two questionnaires have been drawn up, and four reflection groups have been created-in which, a total of 49 teachers and 170 students have participated. The results show that there is a low presence of sustainability in Science of Education degree courses. The teachers express the opinion that they are engaged in sustainable initiatives and have an interest in ethical models. The students express a high degree of interest in receiving sustainability training. Findings provide information for introducing innovation into the university curriculum and the training of teachers and students in order to improve their competency in sustainability.
\end{abstract}

Keywords: competency in sustainability; science of education; students; teachers; higher education

\section{Introduction}

Social commitment is inherent in higher education and thus requires analysis in order to examine the training criteria of sustainability in greater depth. The Rio +20 United Nations Conference on Sustainable Development concluded with the 2030 Agenda for Sustainable Development. At the heart of this Agenda are 17 Sustainable Development Goals (SDGs) that address the main development challenges facing humanity. These SDGs are focused on key systemic barriers to sustainable development, such as inequality, sustainable consumption patterns, weak institutional capacity and degradation of the environment [1].

Tackling these goals demands a radical transformation in our way of thinking and acting. Education is one of the vital factors for achieving the implementation of sustainability in people's daily lives, and therefore we are required to train professionals capable of acting as agents of change and transformation of our socio-environmental reality.

Universities have a crucial role to play in this undertaking, since their function is not only to generate and transfer relevant knowledge, but also to educate and train leaders able to contribute to a (greater) sustainable future [2,3]. Furthermore, the experience and preparation acquired in the universities are essential for overcoming the challenges set by the SDGs. With the signing of international declarations, universities are contributing to this endeavour by their commitment to introducing SDGs into their 
educational policies and practices-not only in their curricula but also in research and social projection [4]. However, different studies have made it clear that the lack of engagement in degree students still exists, and even diminishes when they go on to study at higher levels $[5,6]$.

Given this situation, how can universities put their responsibility for sustainability into practice? According to Moore (2001) [7], it is first necessary to imagine what a "sustainable" university would be like, including the vision of educational programmes of sustainability and sustainable university communities. Sustainability is a concept, a goal and a strategy that seeks the reconciliation of social justice, ecological integrity and the welfare of all the living systems on the planet. Thus, setting out on the road to sustainability in the university means beginning by empowering the university community itself, as well as creating spaces for reflection and collective, inter- and transdisciplinary collaboration [8].

In this way, the inclusion of sustainability in higher education poses a new challenge to the academic system [9] in order to make it an emerging field of research [10]. In recent years, universities have been carrying out activities with varying degrees of success and difficulty in pursuance of this aim (see, for example, $[6,9,11,12])$. Some of the main tasks in this undertaking are environmental management, descriptive case studies, examples of best practice, the integration of sustainability into specific courses, theoretical development in teaching and learning focused on sustainability, and the analysis of university policies, among others $[8,13,14]$.

Nevertheless, there remains a lack of common criteria about which competencies to include and their promotion and evaluation in university degree courses [15-17]—one of the main difficulties being the incorporation of sustainability into study plans [18].

\section{Implementing Sustainability in the Curriculum}

The inclusion of sustainability in the curriculum does not mean introducing environmental content into teaching [16], but rather training people to enable them to critically analyse the interrelations between environmental, social and economic factors in such a way that their decisions are based on more sustainable and socially responsible criteria [19]. With the aim of providing directives to facilitate the implementation of sustainability in the curriculum, in 2005 the CRUE-Spanish Universities (Consejo de Rectores de la Universidad Española-Spanish University Board of Chancellors) drew up a document entitled "Guidelines for the Introduction of Sustainability into the Curriculum" [20], which was subsequently extended in 2011 in accordance with the European Higher Education Area (EHEA). This concerns the training of "participative and proactive people capable of making responsible decisions, acquiring awareness of the challenges posed by globalization, promoting respect for diversity and the culture of peace", as well as consolidating the training strategies for empowering an active citizenship capable of effecting change by direct action.

Different initiatives have been undertaken in universities with the aim of integrating sustainability by means of teaching-the most significant of which are the inclusion of sustainability in the curricula, the development of active pedagogies incorporating sustainability content and assessment systems to foster learning in sustainability (see, for example, $[15,16,21-26])$. These initiatives involve some complexity because they require a change in worldview by teachers as well as specific training.

Furthermore, difficulties arise with the teachers when it comes to their understanding of the concept of "implementing sustainability in the curriculum" and its integration into different subjects, independently of the area of knowledge, since this process requires an innovative and interdisciplinary practical application [3,27]. Although teachers may understand this integration in a theoretical sense, they encounter obstacles when putting it into practice.

The inclusion of sustainability in the university is conditioned by some important factors, including sustainability in the curriculum, appropriate training for teachers, and the conceptions they integrate about sustainability itself. This latter factor has been analysed by Shephard, and Furnari [28], among others, who have found that it is vital to identify which ideas act upon teachers when conducting their teaching tasks. Such ideas play a crucial role in the educational and training processes aimed at equipping students with (more) sustainable habits. 
Based on the existing literature regarding the perceptions and attitudes held by university teaching staff, some conclusions may be drawn about common concerns: diversity regarding points of view, teachers' discourse and understanding of sustainability, and uncertainty about the way in which students learn and how teachers teach the topics in the curriculum. Different levels of commitment to the idea of sustainability education exist about what its aims should be $[13,29,30]$. In the studies by Jones et al. [31] and by Leal-Filho [32] some of the factors limiting academics in the integration of sustainability were identified, such as personal beliefs and values, lack of awareness, time and capacity. Other studies, like those by Reid and Petocz [33], distinguish two extreme conceptions about the integration of sustainability into the curriculum, while one conception envisages the integration of sustainability and teaching, the other regards learning and sustainability as two remotely connected concepts.

Furthermore, the studies by Tsz-Yan, Chow and Wing-Mui [34] indicate the slow and insufficient progress made to integrate sustainability into the curriculum. As pointed out by Aznar et al. [35], 'the literature and research in the field thus far provide very few examples of any great curricular change and the experiences available are scarce and anecdotal' (p. 227). Other studies suggest that even though teachers constitute the mainstay of any innovative process, difficulties exist regarding both their commitment to sustainability and to student training in sustainability [36].

In addition, students who are being trained in university classrooms are faced with a range of difficulties in the understanding of sustainability and its inclusion in their future professional activity. For instance, in studies conducted with teachers about training [37], it was concluded that they understand sustainability as an area of knowledge belonging to the natural sciences that has more to do with the conservation of nature than for the purpose of stimulating critical thinking regarding the prevention and resolution of socio-environmental problems.

Despite being a field that is growing in interest, further research is necessary to investigate more deeply the understanding that both teachers and students have about the challenges that arise when considering the principles on which sustainability education should be based. It is important to recognise the social usefulness of including sustainability in the curriculum, since it is capable of bringing about personal, cultural and economic changes. To that end, the purpose of this work is to consider carefully proposals made by teachers and students that may help to guide both teaching staff and researchers in the direction that leads to such changes.

This research forms part of the R + D + i Education and Social Innovation for Sustainability (Educación e Innovación Social para la Sostenibilidad (EDINSOST)) 'Training project in Spanish universities for professionals as agents of change in order meet the challenges facing society' [8]. A total of 13 degree courses in the fields of engineering and education have participated in the project, imparted in 10 universities throughout Spain (Autonomous University of Madrid, University of Cádiz, University Camilo José Cela, University of Córdoba, University of Girona, International University of Catalonia, Polytechnic University of Catalonia, Technical University of Madrid, University of Salamanca and University of Seville) and with the collaboration of 59 researchers. The purpose of the project is the training of qualified personnel capable of leading the effort to meet the challenges posed by our society by means of integrating sustainability training in the Spanish University System. A diagnosis of both teacher requirements in sustainability training and university student requirements in sustainability learning forms part of these objectives.

Specifically, this paper focuses on the diagnosis of sustainability in terms of curriculum content and competence training on the part of both students and teachers in the Bachelor Degree in Early Childhood Education, the Bachelor Degree in Primary Education and the Bachelor Degree in Pedagogy at the University of Seville, with the aim of introducing innovation into the university curriculum and the training of teachers and students in order to improve their competency in sustainability.

\section{Materials and Methods}

The general objective of the EDINSOST project is to advance educational innovation with the aim of furnishing future graduates with the competences required to help bring about a more sustainable 
society. Among these objectives is an analysis of the type of sustainability training currently being provided in universities [26]. The purpose of this present work is to describe the current situation of sustainability competencies in Science of Education degree courses at the University of Seville. Moreover, it also aims to determine the knowledge and ideas regarding sustainability held by teachers, and to perform a diagnosis of the current state of sustainability learning by students

The authors posed the following questions for determining the presence of sustainability competencies at the University of Seville Science of Education Faculty:

Question 1: What is the presence of sustainability in the curricula of US Science of Education degree courses?

Question 2: Do the teachers think that they have sufficient knowledge to undertake sustainability competencies in the US Science of Education degree courses?

Question 3: What do students think about the level of training they receive for the development of sustainability competencies?

An analysis of the study plans of each degree course has been conducted in order to respond to Question 1. Two questionnaires have been drawn up and four focus groups established in the case of Questions 2 and 3.

This work is focused on the following degree courses-the Bachelor Degree in Early Childhood Education, the Bachelor Degree in Primary Education and the Bachelor Degree in Pedagogy-because they are directly associated with Education from a school standpoint. The target population for this study consists of the students and teachers belonging to the Faculty of Sciences of Education (US), which has enabled investigation into the teaching concepts and practices regarding sustainability in the university context.

\subsection{Data Collection Instruments}

The choice of instruments is based on the object of the study, the problems involved and the focus of the research instruments described below. This has enabled us to gather the information necessary to analyse and explore the field of study [38] and then select the most representative data once the actual situation has thereby been assessed.

The following instruments used in this research have been validated by experts in the EDINSOST Project $[26,39]$ and are employed to analyse the state of sustainability education in Science of Education degree courses at the University of Seville:

(a) A sustainability map of Science of Education degree courses used to analyse the presence of sustainability in the study plans, regarded as written sources of information intended to provide an answer to Question 1.

(b) One questionnaire submitted to teachers and another to students in order to determine their perception of sustainability training, with the intention of providing answers to Questions 2 and 3.

(c) Four focus groups consisting respectively of students and teachers belonging to the US Faculty of Science of Education.

\subsubsection{Sustainability Map of Higher Education Degree}

The Sustainability Map, on which the first research problem is focused, was designed within the framework of the EDINSOST Project and based on documentary sources [26], consultation with the different official sources (e.g., generic and specific competences for the qualification of the degree qualification of the memories and Australian Professional Standards) belonging to Science of Education degree courses, and the incorporation of the sustainability competencies as set out by the CRUE (Consejo de Rectores de la Universidad Española-Spanish University Board of Chancellors) Sustainability Commission in 2015. The Sustainability Map (see Table 1) is used as a rubric for analysing the presence of sustainability competencies in Science of Education degree courses. 
Table 1. Sustainability Map of Higher Education Degree. Source: [26].

\begin{tabular}{|c|c|c|c|c|}
\hline \multirow{2}{*}{ Related Competencies } & \multirow{2}{*}{ Competency Unit } & \multicolumn{3}{|c|}{ Domain Levels (According to the Simplified Miller Pyramid) } \\
\hline & & Level 1. KNOWING & Level 2. KNOWING HOW & Level 3. SHOWING and DOING \\
\hline \multirow{2}{*}{$\begin{array}{l}\text { SUST 1-Critical contextualization of } \\
\text { knowledge, establishing } \\
\text { interrelationships between social, } \\
\text { economic and environmental, local } \\
\text { and/or global problems }\end{array}$} & $\begin{array}{l}\text { 1.1. Understands the functioning of } \\
\text { natural, social and economic systems, as } \\
\text { well as their interrelations and problems, } \\
\text { both at a local and global level }\end{array}$ & $\begin{array}{l}\text { Knows the functioning of natural, social } \\
\text { and economic systems and the mutual } \\
\text { relations between them }\end{array}$ & $\begin{array}{l}\text { Analyses and understands the } \\
\text { relationship between natural systems and } \\
\text { social and economic systems }\end{array}$ & $\begin{array}{l}\text { Is able to imagine and predict the impacts } \\
\text { the changes produced in natural systems } \\
\text { may cause in social and economic } \\
\text { systems and among each other }\end{array}$ \\
\hline & $\begin{array}{l}\text { 1.2. Possesses critical thinking and } \\
\text { creativity, taking advantage of the } \\
\text { different opportunities presented } \\
\text { (information and communications } \\
\text { technology (ICT), strategic plans, } \\
\text { regulations, etc.) in the planning of a } \\
\text { sustainable future }\end{array}$ & $\begin{array}{l}\text { Knows the procedures and resources to } \\
\text { integrate sustainability into educational } \\
\text { projects }\end{array}$ & $\begin{array}{l}\text { Understands and takes advantage of the } \\
\text { opportunities that present themselves in } \\
\text { educational contexts in order to plan } \\
\text { sustainable projects }\end{array}$ & $\begin{array}{l}\text { Provides solutions to educational projects } \\
\text { from a critical and creative viewpoint } \\
\text { with the aim of planning a sustainable } \\
\text { future }\end{array}$ \\
\hline $\begin{array}{l}\text { SUST 2-Sustainable use of resources in } \\
\text { the prevention of negative impacts on } \\
\text { natural and social environments }\end{array}$ & $\begin{array}{l}\text { 2.1. Designs and develops actions, } \\
\text { making decisions that take into account } \\
\text { the environmental, economic, social, } \\
\text { cultural and educational impacts so as to } \\
\text { improve sustainability }\end{array}$ & $\begin{array}{l}\text { Has basic knowledge of identifying } \\
\text { possible socio-environmental impacts } \\
\text { derived from educational actions }\end{array}$ & $\begin{array}{l}\text { Knows how to develop educational } \\
\text { actions that mitigate negative } \\
\text { socio-environmental impacts }\end{array}$ & $\begin{array}{l}\text { Designs and develops educational } \\
\text { activities in which negative } \\
\text { socio-environmental impacts are taken } \\
\text { into account and incorporates mitigating } \\
\text { measures }\end{array}$ \\
\hline $\begin{array}{l}\text { SUST 3-Participation in community } \\
\text { processes that promote sustainability }\end{array}$ & $\begin{array}{l}\text { 3.1. Promotes and participates in } \\
\text { community activities that encourage } \\
\text { sustainability }\end{array}$ & $\begin{array}{l}\text { Recognises himself/herself as an integral } \\
\text { part of his/her surroundings and knows } \\
\text { the community education programmes } \\
\text { that encourage participation and } \\
\text { commitment to socio-environmental } \\
\text { improvement }\end{array}$ & $\begin{array}{l}\text { Is able to interact satisfactorily in } \\
\text { educational community projects, } \\
\text { encouraging participation }\end{array}$ & $\begin{array}{l}\text { Designs and carries out socio-educational } \\
\text { activities in participatory community } \\
\text { processes that promote sustainability }\end{array}$ \\
\hline \multirow[t]{2}{*}{$\begin{array}{l}\text { SUST 4-Application of ethical principles } \\
\text { related to sustainability values in } \\
\text { personal and professional behaviour }\end{array}$} & $\begin{array}{l}\text { 4.1. Is consistent in actions, respecting } \\
\text { and valuing (biological, social and } \\
\text { cultural) diversity and committed to } \\
\text { improving sustainability }\end{array}$ & $\begin{array}{l}\text { Knows the ethical principles of } \\
\text { sustainability and the importance of } \\
\text { respecting diversity in educational } \\
\text { intervention }\end{array}$ & $\begin{array}{l}\text { Understands and integrates the ethical } \\
\text { principles of sustainability in his/her } \\
\text { actions, considering nature as a good in } \\
\text { itself and transmitting the importance of } \\
\text { education for change in the relationship } \\
\text { between human beings and the } \\
\text { socio-cultural environment }\end{array}$ & $\begin{array}{l}\text { Is able to design and/or manage } \\
\text { educational projects taking into account } \\
\text { ecological ethics to improve quality of life } \\
\text { and to promote the common good }\end{array}$ \\
\hline & $\begin{array}{l}\text { 4.2. Promotes education in values } \\
\text { oriented to the formation of responsible, } \\
\text { active and democratic citizens }\end{array}$ & $\begin{array}{l}\text { Takes into account promoting integral } \\
\text { and sustainable human development as } \\
\text { the basic purpose of the formation of } \\
\text { citizenship }\end{array}$ & $\begin{array}{l}\text { Critically analyses and assesses the } \\
\text { consequences his/her personal and } \\
\text { professional actions may have on the } \\
\text { integral development of students and on } \\
\text { promoting sustainable human } \\
\text { development }\end{array}$ & $\begin{array}{l}\text { Designs and develops educational } \\
\text { intervention proposals that integrate the } \\
\text { values of sustainability and which result } \\
\text { in justice and the common good }\end{array}$ \\
\hline
\end{tabular}


The Sustainability Map is arranged into competency units and domain levels. Each competency is divided into three simplified tiers using the Miller Pyramid [40], which establishes three levels of competency acquisition in the medical profession (and is applicable to other professions), as can be seen in Figure 1.

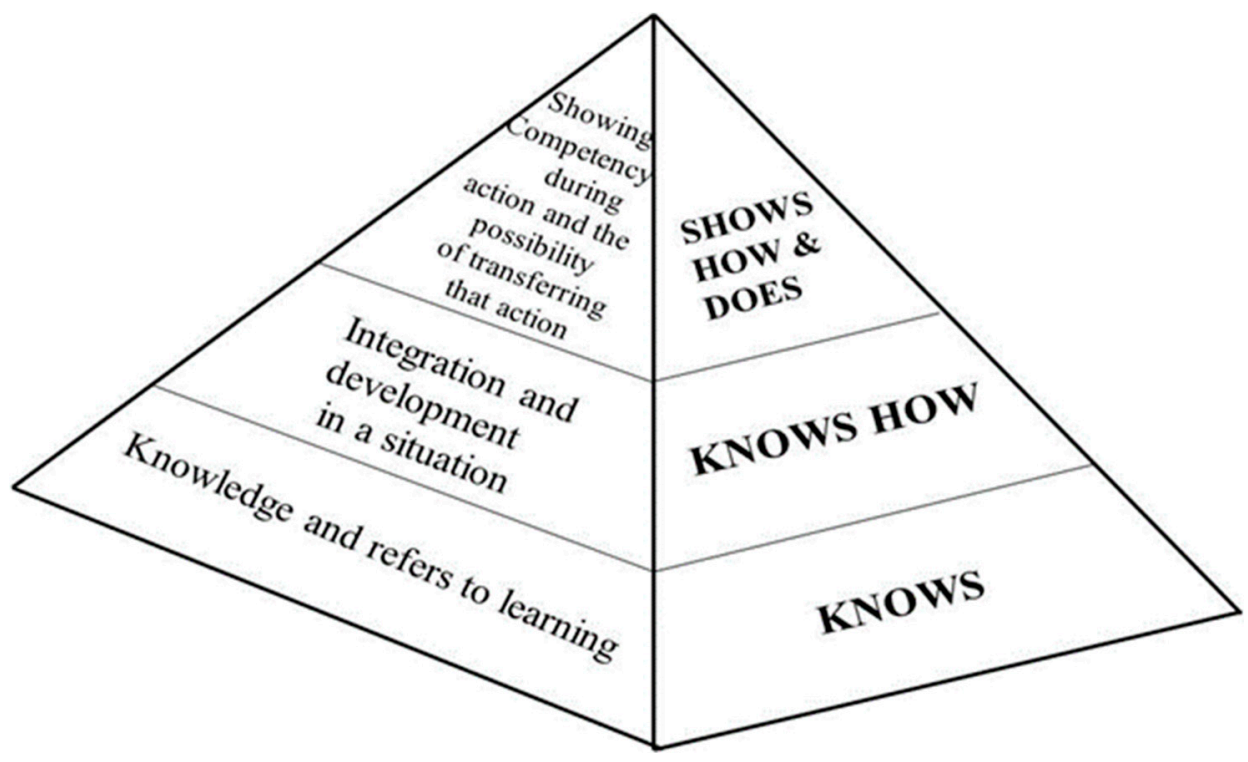

Figure 1. Miller's Pyramid.

The first domain level corresponds to knowledge and refers to "knows"; the second domain level corresponds to the integration of knowledge and skills, "knowing how"; the third domain level is linked to the demonstration of competence in action and the possibility of transferring it to other situations, "shows how and do".

\subsubsection{The Sustainability Questionnaires}

The questionnaires belonging to the EDINSOST project were submitted to the teachers and students and the data was subsequently analysed. To that end, two online questionnaires were designed to facilitate access to a total of 219 participants- 170 of whom were students and 49 teachers. Validation of the questionnaires was conducted by means of an internal consistency reliability test. All the groups of variables present a Cronbach Alpha coefficient greater than 0.7; that is, they are all close to 1 , which is the optimal consistency value.

\subsubsection{Focus Groups}

The establishment of the focus groups was preceded by the creation of a system of categories corresponding to the objectives and problems of the research. Each category was characterised, and a script was then drawn up for the focus groups and the questionnaires. Finally, the four focus groups were organized with the participation of 12 students and 12 teachers ( 6 in each group) belonging to all the degree courses, priority being given in the case of the students to those in the third and fourth years of study. A preliminary focus group had been created and analysed beforehand at the University of Murcia to check the script and the category system-this latter being designed differently for students and teachers. In what follows, we present a description of both categories, that of the student group (S) and the teachers' group (T), and finally a code corresponding to the initials of each title of the category, as can be seen in Table 2 . 
Table 2. Category system for the analysis of the focus groups. Source: Provided by the authors on the basis of Educación e Innovación Social para la Sostenibilidad (EDINSOST) (2017).

\begin{tabular}{|c|c|c|c|c|}
\hline Category & Description & $\mathrm{S}$ & $\mathrm{T}$ & Code \\
\hline Sustainability concept & Statements referring to what is understood by sustainability. & $\mathrm{X}$ & $\mathrm{X}$ & CS \\
\hline Importance of sustainability & $\begin{array}{l}\text { Statements referring to the importance of sustainability in all its spheres (academic, } \\
\text { personal, professional ... ). }\end{array}$ & $\mathrm{X}$ & $\mathrm{X}$ & IS \\
\hline Participation & $\begin{array}{l}\text { Statements referring to participation in projects and programmes, and possible } \\
\text { obstacles to participation. }\end{array}$ & $\mathrm{X}$ & $\mathrm{X}$ & $\mathrm{P}$ \\
\hline Prior knowledge & $\begin{array}{l}\text { Statements referring to knowledge believed to be possessed prior to starting at } \\
\text { university and about personal and professional conduct aimed at the creation of } \\
\text { environmental awareness and sustainability values. }\end{array}$ & $x$ & & $\mathrm{CP}$ \\
\hline $\begin{array}{l}\text { Preparation in university } \\
\text { studies }\end{array}$ & $\begin{array}{l}\text { Comments about competencies they believe they have acquired throughout their } \\
\text { university course. }\end{array}$ & $\mathrm{X}$ & & PU \\
\hline Subjects & $\begin{array}{l}\text { Statements about the subject(s) studied throughout the course in which they think } \\
\text { sustainability has been most incorporated. }\end{array}$ & $\mathrm{X}$ & $\mathrm{X}$ & A \\
\hline $\begin{array}{l}\text { Methodologies and } \\
\text { resources/Didactic strategies }\end{array}$ & $\begin{array}{l}\text { References to methodologies, resources, didactic strategies, dynamics etc., in which } \\
\text { they believe they have worked on sustainability. }\end{array}$ & $x$ & $x$ & MR \\
\hline $\begin{array}{l}\text { Competency in } \\
\text { sustainability }\end{array}$ & $\begin{array}{l}\text { References about whether or not they feel prepared and competent in the matter of } \\
\text { sustainability. }\end{array}$ & $x$ & $\mathrm{X}$ & CS \\
\hline $\begin{array}{l}\text { Roles, relations and } \\
\text { classroom atmosphere }\end{array}$ & $\begin{array}{l}\text { Comments about the characteristics of teachers' and students' roles, as well as } \\
\text { relations in the classroom and the atmosphere they think is conducive to the } \\
\text { acquisition of sustainability competencies. }\end{array}$ & $x$ & $x$ & RRC \\
\hline Assessment & $\begin{array}{l}\text { Statements about how to assess sustainability competencies and the concerns and } \\
\text { ideas expressed about this. }\end{array}$ & $x$ & $\mathrm{X}$ & $\mathrm{E}$ \\
\hline Others & Complementary information not categorizable in the above. & $x$ & $x$ & S \\
\hline $\begin{array}{l}\text { Teacher motivation and } \\
\text { commitment }\end{array}$ & $\begin{array}{l}\text { Aspects reflecting the interest for putting sustainability into teaching practice from } \\
\text { the point of view of intrinsic motivation regarding a lifestyle that is respectful of the } \\
\text { environment. }\end{array}$ & & $x$ & $\mathrm{MCP}$ \\
\hline Ethical model & $\begin{array}{l}\text { Statements referring to personal and professional conduct aimed at the creation of } \\
\text { awareness of sustainability and the values associated with it. }\end{array}$ & & $x$ & ME \\
\hline Self-assessment & $\begin{array}{l}\text { Statements referring to the level of effectiveness and efficiency of the resources } \\
\text { employed. }\end{array}$ & & $x$ & $\mathrm{AE}$ \\
\hline Curricular organisation & $\begin{array}{l}\text { Possible obstacles/assistance encountered by teachers when organising active } \\
\text { learning strategies (Service learning, project-based learning ... ), arising from the } \\
\text { disciplinary organisation of the study plans. Proposals for improvement. }\end{array}$ & & $\mathrm{x}$ & $\mathrm{OC}$ \\
\hline Teacher training & $\begin{array}{l}\text { Difficulties/assistance encountered by teachers for applying sustainability training } \\
\text { strategies arising from their own lack of training. }\end{array}$ & & $x$ & FP \\
\hline Expository teaching & $\begin{array}{l}\text { An entrenched tendency to use the expository method of teaching in the classroom, } \\
\text { which hinders the introduction of active strategies and participative learning. }\end{array}$ & & $x$ & $\mathrm{EE}$ \\
\hline Presence or absence & $\begin{array}{l}\text { Refers to the presence or absence of non-curricular activities involving collaboration } \\
\text { with social entities outside the university, in order to strengthen the connection } \\
\text { between learning and the reality of professional service and practice. }\end{array}$ & & $x$ & US \\
\hline Institutional support & $\begin{array}{l}\text { Difficulties/assistance arising from the lack/existence of a university policy to } \\
\text { support and strengthen teaching innovation programmes aimed at integrating active } \\
\text { methodologies for sustainability training. }\end{array}$ & & $x$ & AI \\
\hline Best practice & $\begin{array}{l}\text { Refers to best practice in the classroom regarding the use of resources, and attention } \\
\text { to students with special needs. }\end{array}$ & & $x$ & $\mathrm{BP}$ \\
\hline $\begin{array}{l}\text { Extra-university student } \\
\text { training }\end{array}$ & $\begin{array}{l}\text { Refers to the sustainability training received outside the academic sphere of the } \\
\text { university. }\end{array}$ & & $x$ & FE \\
\hline Holistic vision & $\begin{array}{l}\text { Refers to the three dimensions of environmental, socio-cultural and economic } \\
\text { sustainability. }\end{array}$ & & $x$ & VH \\
\hline Transversality/Coordination & $\begin{array}{l}\text { Need for/examples of making sustainability transversal throughout the course and } \\
\text { improving inter- and intra-departmental coordination mechanisms. }\end{array}$ & & $x$ & $\mathrm{TC}$ \\
\hline
\end{tabular}

\section{Results}

\subsection{Analysis of the Presence of Sustainability in Science of Education Degree Courses}

The curricula of the Bachelor Degree in Early Childhood Education (ECE), the Bachelor Degree in Primary Education (PE) and the Bachelor Degree in Pedagogy (P) contain 134 subjects. Table 3 shows the presence of sustainability identified in the analysis of the degree courses using the Sustainability Map. The information derived from the analysis on the presence of sustainability in the curriculum and how it is interpreted in the form of competencies and domain levels. One may observe the number of subjects that develop sustainability in each degree course. 
Table 3. Analysis of the presence of sustainability in Science of Education Degree courses. (The Bachelor Degree in Early Childhood Education (ECE), the Bachelor Degree in Primary Education (PE) and the Bachelor Degree in Pedagogy (P).).

\begin{tabular}{ccccccccccc}
\hline \multicolumn{1}{c}{ Level 1. KNOWING } & \multicolumn{1}{c}{$\begin{array}{c}\text { Level 2. KNOWING } \\
\text { HOW }\end{array}$} \\
$\begin{array}{c}\text { Related } \\
\text { Competencies }\end{array}$ & ECE & PE & P & ECE & PE & P & ECE & PE & P & SHOWING and \\
DOING & Total \\
\hline SUST 1 & 4 & 5 & 10 & 4 & 0 & 4 & 1 & 0 & 1 & 29 \\
SUST 2 & 4 & 0 & 4 & 0 & 0 & 2 & 0 & 0 & 1 & 11 \\
SUST 3 & 1 & 0 & 4 & 3 & 0 & 2 & 0 & 0 & 1 & 11 \\
SUST 4 & 14 & 4 & 3 & 3 & 0 & 1 & 2 & 2 & 1 & 30 \\
Total & 23 & 9 & 21 & 10 & 3 & 9 & 3 & 2 & 4 & 84 \\
\hline
\end{tabular}

The results indicate that the level of presence of sustainability content in the curricula of ECE, $\mathrm{PE}$ and $\mathrm{P}$ is relatively low. Sustainability content is present in 37 of the 134 subjects belonging to the three degree courses. Table 3 shows the subjects in SUST1, SUST2, SUST3 and SUST4 in the corresponding domain levels (henceforth denoted as DL). Thus, one observes more than 37 subjects in Table 3, since a particular subject can be found in more than one competency. The number of subjects with sustainability presence is higher in the Bachelor Degree in Early Childhood Education and Pedagogy. The course with the least presence of sustainability in its programmes and official documents is the Bachelor Degree in Primary Education.

Significant differences are found in the number of subjects that each degree course devotes to developing sustainability. The Domain Levels (DLs) found in each course also vary significantly. Domain Level 1 has the highest presence with 53 subjects, followed by Level 2 with 22 subjects. Level 3 is the least developed in the Educational degree courses with only 9 subjects. This indicates that the subjects belonging to the Educational degree courses develop sustainability from a theoretical perspective, and to a lesser extent in Level 2 (Knowing how). No significant presence of sustainability competencies exists in Level 3 (Showing and doing).

In addition, the results show that the competencies SUST 1 and SUST 4 in the educational degree courses are those with the highest presence with 29 and 30 subjects, respectively, followed by SUST 3 with 11 subjects, and finally by SUST 2 also with 11. Thus, academic training in Science of Education degree courses has the highest presence of critical contextualisation of knowledge, the creation of interrelations with social, economic, environmental, local and/or global problems (SUST 1), and the application of ethical principles regarding sustainability values in personal and professional behaviour.

\subsection{What Teachers Think about Whether They Have Sufficient Knowledge to Undertake Sustainability Competencies}

Table 4 shows the results from the questionnaire submitted to 49 teachers of the three Educational degree courses about how they regard their own knowledge of sustainability competencies and its inclusion in teaching practice. It is necessary to point out that the information gathered in the questionnaire refers to competencies SUST1, SUST2 and SUST3, while information on SUST 4 is not gathered explicitly, but rather from questions regarding teaching strategies and methodologies. Thus, this information does not appear in Table 4 because it has little bearing on the objectives of the present work.

With regard to Domain Level 1 (Knowing), the teachers state that they are mainly situated in N3 of all competencies, except for competency SUST 1 (1-2), where they state that they are located in N2. As regards Domain Level 2 (Knowing how), most responses are found in N3 for competencies SUST 1 and SUST 2, while for competency SUST 3 the majority are located in N2 and N4. Finally, where Domain Level 3 (Showing and doing) is concerned, teachers are situated mainly in N3 for SUST 1 and SUST 2, and to a lesser extent in N2 for SUST 3 and SUST 4. 
Table 4. Teachers' perception of sustainability competencies. Source: Provided by the authors on the basis of EDINSOST (2017).

\begin{tabular}{|c|c|c|c|c|c|c|c|c|c|c|c|c|c|c|c|c|}
\hline & \multirow[t]{2}{*}{$\begin{array}{l}\text { Unit of } \\
\text { Competence } \\
\text { (UC) }\end{array}$} & \multicolumn{5}{|c|}{ Level 1. KNOWING } & \multicolumn{5}{|c|}{ Level 2. KNOWING HOW } & \multicolumn{5}{|c|}{$\begin{array}{l}\text { Level 3. SHOWING and } \\
\text { DOING }\end{array}$} \\
\hline & & No & N1 & N2 & N3 & N4 & No & N1 & N2 & N3 & N4 & No & N1 & N2 & N3 & N4 \\
\hline \multirow{2}{*}{ SUST 1} & $1-1$. & 3 & 4 & 7 & 24 & 11 & 2 & 3 & 7 & 26 & 11 & 6 & 3 & 4 & 22 & 14 \\
\hline & $1-2$ & 2 & 4 & 21 & 17 & 5 & 3 & 2 & 17 & 19 & 8 & 3 & 4 & 14 & 17 & 11 \\
\hline SUST 2 & $2-1$ & 1 & 2 & 11 & 25 & 10 & 2 & 3 & 15 & 21 & 8 & 2 & 6 & 17 & 15 & 9 \\
\hline SUST 3 & 3-1. & 3 & 4 & 10 & 20 & 12 & 5 & 7 & 14 & 9 & 14 & 4 & 10 & 17 & 8 & 10 \\
\hline
\end{tabular}

Generally speaking, the results suggest that teachers are not found in the highest level (N4) in any of the competencies. The findings indicate the need to improve teacher training in sustainability skills.

\subsection{Student Perception of Their Knowledge of Sustainability Competencies}

Table 5 shows the results based on the analysis of the questionnaire submitted to a total of 170 students belonging to the three degrees regarding their training in sustainability competencies.

Table 5. Student perception of their knowledge of sustainability competencies. Source: Provided by the authors on the basis of EDINSOST (2017).

\begin{tabular}{|c|c|c|c|c|c|c|c|c|c|c|c|c|c|c|c|c|}
\hline & \multirow[t]{2}{*}{$\begin{array}{c}\text { Unit of } \\
\text { Competence } \\
\text { (UC) }\end{array}$} & \multicolumn{5}{|c|}{ Level 1. KNOWING } & \multicolumn{5}{|c|}{ Level 2. KNOWING HOW } & \multicolumn{5}{|c|}{$\begin{array}{l}\text { Level 3. SHOWING and } \\
\text { DOING }\end{array}$} \\
\hline & & No & N1 & N2 & N3 & N4 & No & N1 & N2 & N3 & N4 & No & N1 & N2 & N3 & N4 \\
\hline \multirow[b]{2}{*}{ SUST 1} & $1-1$. & 0 & 16 & 78 & 71 & 5 & 0 & 26 & 82 & 57 & 5 & 0 & 13 & 64 & 85 & 8 \\
\hline & $1-2$ & 0 & 26 & 69 & 66 & 9 & 0 & 19 & 74 & 65 & 12 & 1 & 29 & 75 & 56 & 9 \\
\hline SUST 2 & $2-1$ & 0 & 13 & 56 & 84 & 17 & 1 & 16 & 69 & 70 & 14 & 0 & 19 & 72 & 69 & 10 \\
\hline SUST 3 & $3-1$. & 1 & 29 & 71 & 57 & 12 & 2 & 14 & 46 & 80 & 28 & 0 & 21 & 74 & 61 & 14 \\
\hline \multirow{2}{*}{ SUST 4} & 4-1. & 1 & 28 & 70 & 59 & 12 & 0 & 28 & 83 & 51 & 8 & 0 & 26 & 69 & 68 & 7 \\
\hline & 4-2. & 1 & 12 & 42 & 62 & 53 & 0 & 12 & 48 & 73 & 37 & 0 & 15 & 72 & 71 & 12 \\
\hline
\end{tabular}

From the analysis of this table, a rating of more than $40 \%$ is considered to be relevant (agreement between researchers); that is, a total of 68 students or more who responded affirmatively to a question in the awareness that a figure of $50 \%$ would be desirable. SUST 1 is the only competency that DL3 is greater than $50 \%$.

It is worth pointing out that there is no competency in which N4 is reached in the Domain Levels (DLs). Levels N2 are N3 those that stand out in the Competency Unit 1.1. It is also worth emphasising, as in DL3, that almost all the competency units are found in Levels N2 and N3, except in the case of Competency Units 1.2 and 3.1, even though they register a high rating. The students state that they have developed sustainability competencies to a great extent, which contrasts with the analysis of the curricula regarding sustainability and coincides with the good perception expressed by the teachers themselves. Nevertheless, it is true that both students and teachers have room for improvement in order to reach $\mathrm{N} 4$ at all the levels of progression.

\subsection{Analysis of the Information Units Regarding the Opinion of Science of Education Teachers and Students about Sustainability}

The results from the questionnaires are complemented by the results obtained from the analysis of 2 teacher focus groups and 2 student focus groups (each group consisting of six members), with a total participation of 24 students and teachers.

Table 6 shows the analysis of the Information Units (henceforth denoted by IU) of sustainability in regard to the teachers and students belonging to Science of Education degree courses. The significance 
of each IU is represented by a repetition frequency of at least more than three different individuals ( $\mathrm{f}>$ 3) based on the triangulation of data [41].

Table 6. Analysis of the information units regarding the opinion of Science of Education teachers and students about sustainability. Source: Provided by the authors on the basis of EDINSOST (2017).

\begin{tabular}{ccccccccc}
\hline Code & \multicolumn{2}{c}{ Teacher $\mathbf{1}$} & \multicolumn{2}{c}{ Student $\mathbf{1}$} & \multicolumn{2}{c}{ Teacher 2 } & \multicolumn{2}{c}{ Student 2 } \\
\hline & U.I & f > 3 & U.I & f > 3 & U.I. & f > 3 & U.I. & f > 3 \\
\hline CS & 11 & 6 & 4 & 6 & 10 & 4 & 4 & 4 \\
IS & 6 & - & - & - & 6 & 4 & - & - \\
P & - & - & 5 & 4 & - & - & 5 & 4 \\
CP & - & - & 6 & 6 & - & - & 19 & 6 \\
PU & - & - & 20 & 6 & - & - & - & - \\
A & 5 & - & 4 & - & 5 & 4 & 4 & 5 \\
MR & 7 & 5 & 13 & 6 & 7 & 6 & 14 & 6 \\
CS & - & - & 7 & 5 & - & - & 13 & 6 \\
RRC & 4 & 4 & 3 & - & 4 & 4 & 4 & 4 \\
S & - & - & 3 & - & - & - & - & - \\
MCP & 3 & 4 & - & - & 3 & - & 3 & - \\
ME & 6 & 5 & - & - & 6 & 6 & 3 & - \\
AE & 1 & - & - & - & 1 & - & - & - \\
OC & 5 & 4 & - & - & 5 & 6 & 13 & 5 \\
FP & 4 & 4 & - & - & 4 & 5 & - & - \\
EE & - & - & - & - & - & - & 3 & - \\
US & 2 & - & - & - & 2 & - & 4 & - \\
AI & 14 & 4 & - & - & 14 & 6 & - & - \\
BP & 7 & 5 & - & - & 7 & 6 & - & - \\
FE & 3 & - & - & - & 3 & - & - & - \\
VH & 13 & 4 & - & - & 14 & 5 & 4 & 4 \\
TC & 9 & 4 & - & - & 9 & 5 & - & - \\
\hline
\end{tabular}

From the results, we extract that the teachers state that they understand sustainability in all the Domain Levels (DLs): Level 1 (Knowing), Level 2 (Knowing how) and Level 3 (Showing and doing), since 21 significant Information Units (IU) exist that refer to the conception of sustainability category, with code CS (21-CS). Significant reference is made to the three dimensions of sustainability: environmental, socio-cultural and economic $(27-\mathrm{VH})$.

Likewise, we extract from the results that the teachers believe that the lack of institutional and holistic support for sustainability in the education degrees is a fact (28-AI). This is closely related to the Transversality Category (TC), where both teachers and students agree that transversality is necessary for the real and effective implementation of sustainability.

The students state that they possessed prior knowledge of sustainability (19-PK) before entering university, making reference to sustainability competencies acquired during their university studies (20-PU).

Furthermore, the teachers (14-MR) and the students (27-MR) agree that development of sustainability competencies in the degree courses depends largely on the methodologies, resources, categories, didactic strategies and dynamics, whether or not they are conducive to sustainability.

Regarding the idea of best practice at the university to enable the degree courses to develop sustainability training, the results show that many and varied teaching practices exist that are conducive to the development of sustainability competencies (8-RRC). Similarly, the teachers state that the incorporation of best practice in sustainability largely depends on the teachers' own ideology, without in many cases prior planning of teaching projects.

The students state that they feel unprepared for incorporating the sustainability dimension into their professional careers (20-CS), which is in agreement with the few notions they say they have of some of the domain levels of sustainability competencies. 


\section{Discussion}

The first question to be dealt with in this research work refers to the analysis of the presence of sustainability in the curricula of the different degrees in Education Sciences at the US. The relevant finding is that it is present in less than $30 \%$ of these grades.

It occurs mainly in the level of acquisition of competency 1 (DL1 Knowledge), with 19\% of the subjects. Sustainability is present in the degrees of Education as theoretical knowledge. As stated by [42], alternative pedagogical approaches to traditional ones have not yet been widely used to transmit sustainability content in higher education.

9\% are found in Level 2 competence acquisition (DL2 Know how), while in Level 3 competence acquisition (DL3 Show and do) this figure is only $4.5 \%$.

Therefore, of the 4 competences of the CRUE, the SUST 1 is present with $13 \%$ of the subjects and SUST 4 with $21 \%$ of the subjects. Others have no significant representation in the Degrees of Education of the Faculty of Education Sciences at the University of Seville.

One may extract from the data that the academic training in sustainability of the Degrees of Education of the US consists mainly in the critical contextualization of knowledge, interrelations with social, economic and environmental problems, and/or in the application of ethical principles relating to the values of sustainability in personal and professional behaviour.

In relation to the second research question concerning the knowledge that teachers have for including sustainability competencies in their teaching practice, it follows that to a large extent teacher in the Faculty of Educational Sciences do not feel prepared to develop sustainability competencies. Their responses to the questionnaire, in which there were 4 levels of response from 1 to 4 , place them mainly in N3 in all competencies, except in Competition Unit 1.2. In this Unit, they are considered to have a lower rating. This unit of competences refers to whether or not they possess critical reflection and creativity, taking advantage of the different opportunities presented (Information and communications technology-ICT, strategic plans, regulations, etc.) for planning a sustainable future. Similarly, in the capacity to show and do, serious in DL2, these teachers rank the lowest. The teachers acknowledge that they have knowledge about sustainability. This is concluded from their answers to the questionnaire at the highest levels of response. Teachers are familiar with the concept and are motivated and interested in including it in their teaching programmes. However, they do not feel prepared to explore the issue further and address sustainability through programmes, strategies, ICT and other alternatives.

Regarding question 3, students at the University of Seville consider that they have knowledge about the subject in the four competences (SUST1, SUST2, SUST3 and SUST4). However, in none of these competences are answers obtained in the scale or level 4; that is to say, the highest qualification. On the contrary, their classifications are mainly in N2. The knowledge about sustainability that students claim to have comes mainly from knowledge acquired before starting university, as shown by the analysis of discussion groups. The teachers state that they pursue sustainable initiatives, as well as being interested in ethical models that enable them to carry out actions and best practices for sustainability. However, this is insufficient; according to the results, more institutional support is needed to guide both individuals and society in general towards a sustainable world.

Data from written sources and from teachers do not match students' ideas, as they themselves claim to have knowledge about sustainability competencies. However, they express their uncertainty and lack of readiness to incorporate sustainability criteria into their professional activity.

The findings reveal a low knowledge of sustainability in teachers and students, so that competencies in sustainability are not incorporated into the Education Sciences degrees at the University of Seville. These findings shed a critical light on the consequences for teachers in the future in terms of their preparation and training in sustainability competencies, as it is necessary to improve such training in the Educational Grade courses at the US. By 2030, all learners will have acquired the skills, values and forms needed for sustainable societies through education for sustainable development [43]. 
The concept of sustainability is complex and holistic, which can lead to confusion about how it should be understood. This also explains why the Degree Map does not reflect any specific line of work that can be followed in sustainability competencies in these degrees.

\section{Conclusions}

The aim of this research work is to understand the presence of sustainability in the teaching at the University of Seville and in the conceptions of its teachers and students. The main findings are the scarce presence of sustainability in Science of Education degree courses, especially in the Degree in Primary Education. It is also concluded that teachers feel motivated and show interest in working on sustainability, although they develop it individually without the explicit help or support of the institution. In addition, teachers feel insecure about both the concept of education for sustainability and the competence for sustainability.

Likewise, the results show that, although students of Education Sciences at the University of Seville are aware of the importance of education for sustainability for their professional future, they do not feel that their academic training prepares them to apply it and evaluate it according to the criteria of competence for sustainability.

Universities in the 21st century are obliged to face the challenges that demand a new educational model in accordance with social expectations and based on the values of sustainability.

The analysis of sustainability in a given context requires careful consideration of how sustainability can be carried out in practice at the university institution. In addition, education for sustainability should be a subject of study for all students, regardless of their educational level. Education ceases to be an end in itself and becomes an instrument to promote the necessary changes in order to ensure sustainable development.

The challenge is to take into account all the means of transmitting existing knowledge in programmes, as well as measures to reform capacities, values, aptitudes and competencies to act in accordance with nature. A society with a high degree of sophisticated knowledge should be able to ensure its own existence.

The views of the teachers and students of this university are indispensable for addressing the revision and renewal of curricula at a time when sustainability is an emerging need. The common approach has been to conduct research on institutions and curricula, but rarely on teacher and student discourse when studying sustainability education, as pointed out in the work by Melles [30]. Progress towards Education for Sustainable Development must take into account not only competencies for sustainability, but also discourses about change and ways of thinking in the academic world in order to create a new educational paradigm. One of the challenges is to determine how the curriculum, through the subjects studied and teaching strategies, can improve students' conceptions of sustainability in the Educational Sciences.

\section{Limitations of the Study}

As this is a study of a single institution, the results cannot be generalized to other institutions. For this reason, each university participating in the Edinsost project is carrying out its own study.

Author Contributions: Introduction, investigation, methodology, resources, validation, writing-review and editing, visualization, C.S.-E., R.V.-H., J.R.-M. and D.L.-D.; Writing一original draft preparation and data curation: C.S.-E. and R.V.-H.; Project administration, C.S.-E.

Funding: This research was funded by the EDINSOST Project "Education and Social Innovation for Sustainability. Training at Spanish universities of professionals as agents of change to face the challenges of society", funded by the "R \& D State programme oriented towards the challenges facing society" of the Spanish Ministry of Economy and Finance [Ref. EDU 2015-65574-R].

Conflicts of Interest: The authors declare no conflict of interest. 


\section{References}

1. Rieckmann, M. Education for Sustainable Development Goals: Learning Objectives; UNESCO: Paris, France, 2017.

2. Scott, W.; Gough, S. Universities and sustainable development: The necessity for barriers to change. Perspect. Policy Pract. High. Educ. 2007, 11, 107-115. [CrossRef]

3. Tilbury, D. Higher Education's Commitment to Sustainability: From Understanding to Action. J. Educ. Sustain. Dev. 2012, 6, 361.

4. Wright, T. University presidents' conceptualizations of sustainability in higher education. Int. J. Sustain. High. Educ. 2010, 11, 61-73. [CrossRef]

5. Cech, E.A.; Sherick, H.M. Depoliticization and the structure of engineering education. In International Perspectives on Engineering Education; Springer: Cham, Switzerland, 2015; pp. 203-216.

6. Segalàs, J.; Ferrer-Balas, D.; Mulder, K.F. What do engineering students learn in sustainability courses? The effect of the pedagogical approach. J. Clean. Prod. 2010, 18, 275-284. [CrossRef]

7. Moore, G. Corporate social and financial performance: An investigation in the U.K. Supermarket industry. J. Bus. Ethics 2001, 34, 299-315. [CrossRef]

8. Sánchez Carracedo, F.; Segalàs, J.; Cabré, J.; Climent, J.; López, D.; Martín, C.; Vidal, E. El proyecto EDINSOST: Inclusión de los ODS en la educación superior. In Proceedings of the VII Congr. Univ. y Coop. al Desarro, Madrid, Spain, 29-31 March 2017.

9. Lozano, R. Incorporation and institutionalization of SD into universities: Breaking through barriers to change. J. Clean. Prod. 2006, 14, 787-796. [CrossRef]

10. Barth, M. Implementing sustainability in higher education: Learning in an age of transformation. In Routledge Studies in Sustainable Development; Routledge: London, UK, 2015.

11. Segalàs, J.; Ferrer-Balas, D.; Svanström, M.; Lundqvist, U.; Mulder, K.F. What has to be learnt for sustainability? A comparison of bachelor engineering education competences at three European universities. Sustain. Sci. 2009, 4, 17-27. [CrossRef]

12. Lidgren, A.; Rodhe, H.; Huisingh, D. A systemic approach to incorporate sustainability into university courses and curricula. J. Clean. Prod. 2006, 14, 797-809. [CrossRef]

13. Cotton, D.; Bailey, I.; Warren, M.; Bissell, S. Revolutions and second-best solutions: Education for sustainable development in higher education. Stud. High. Educ. 2009, 34, 719-733. [CrossRef]

14. Fien, J. Advancing sustainability in higher education: Issues and opportunities for research. High. Educ. Policy 2002, 15, 143-152. [CrossRef]

15. Disterheft, A.; Ferreira da Silva Caeiro, S.S.; Ramos, M.R.; de Miranda Azeiteiro, U.M. Environmental Management Systems (EMS) implementation processes and practices in European higher education institutions-Top-down versus participatory approaches. J. Clean. Prod. 2012, 31, 80-90. [CrossRef]

16. Barrón, A.; Navarrete, A.; Ferrer-Balas, D. Sostenibilización curricular en las universidades españolas. ¿ha llegado la hora de actuar? La Revista Eureka Sobre Enseñanza y Divulgación De Las Ciencias 2010, 7, 388-399. [CrossRef]

17. Lozano, R. The state of sustainability reporting in universities. Int. J. Sustain. High. Educ. 2011, 12, 67-78. [CrossRef]

18. Sterling, S.; Thomas, I. Education for sustainability: The role of capabilities in guiding university curricula. Int. J. Innov. Sustain. Dev. 2006, 1, 349. [CrossRef]

19. Vilches, A.; Gil Pérez, D. Ciencia de la Sostenibilidad: ¿Una nueva disciplina o un nuevo enfoque para todas las disciplinas? Rev. Iberoam. Educ. 2015, 69, 39-60. [CrossRef]

20. CADEP. Directrices Para La Introducción De La Sostenibilidad En El Curriculum (Review 2005); CADEP: Asunción, Paraguay, 2011; pp. 1-7.

21. Albareda-Tiana, S.; García-González, E.; Jiménez-Fontana, R.; Solís-Espallargas, C. Implementing Pedagogical Approaches for ESD in Initial Teacher Training at Spanish Universities. Sustainability 2019, 11, 4927. [CrossRef]

22. Calder, W.; Clugston, R.M. International efforts to promote higher education for sustainable development. Plan. High Educ. 2003, 31, 30-44.

23. Antúnez López, M. Problemática Del Proceso De Sostenibilización Curricular En El Contexto Universitario Español: La Formación Del Profesorado Como Catalizador. Ph.D. Thesis, Universidad de Córdoba, Córdoba, Spain, 2017. 
24. de Geli Ciurana, A.M.; Leal Filho, W. Education for sustainability in university studies. Int. J. Sustain. High. Educ. 2006, 7, 81-93. [CrossRef]

25. Michelsen, G.; Adomßent, M.; Martens, P.; Von Hauff, M. Sustainable development-background and context. In Sustainability Science; Springer: Dordrecht, The Netherlands, 2016; pp. 5-29.

26. Sánchez-Carracedo, F.; Ruiz-Morales, J.; Valderrama-Hernández, R.; Muñoz-Rodríguez, J.M.; Gomera, A. Analysis of the presence of sustainability in Higher Education Degrees of the Spanish university system. Stud. High. Educ. 2019, 11,1-18. [CrossRef]

27. Morilla, M.F.; Camacho, M.T.F.; Tiana, S.A. Sostenibilización curricular en la Educación Superior: Propuesta metodológica. Opción 2015, 31, 284-304.

28. Shephard, K.; Furnari, M. Exploring what university teachers think about education for sustainability. Stud. High. Educ. 2013, 38, 1577-1590. [CrossRef]

29. Cebrián, G.; Junyent, M. Competencies in Education for Sustainable Development: Exploring the Student Teachers' Views. Sustainability 2015, 7, 2768-2786. [CrossRef]

30. Melles, G. Views on education for sustainable development (ESD) among lecturers in UK MSc taught courses. Int. J. Sustain. High. Educ. 2019, 20, 115-138. [CrossRef]

31. Jones, P.; Selby, D.; Sterling, S. Sustainability Education: Principles and Practices across Higher Education; Earthscan: New York, NY, USA, 2010.

32. Filho, W.L. About the Role of Universities and Their Contribution to Sustainable Development. High. Educ. Policy 2011, 24, 427-438. [CrossRef]

33. Reid, A.; Petocz, P. University Lecturers' Understanding of Sustainability. High. Educ. 2006, 51, 105-123. [CrossRef]

34. Cheung, Y.T.Y.; Chow, C.F.; So, W.W.M. A train-the-trainer design for green ambassadors in an environmental education programme on plastic waste recycling. Int. Res. Geogr. Environ. Educ. 2018, 27, 24-42. [CrossRef]

35. Aznar-Minguet, P.; Ull, M.A.; Martínez-Agut, M.P.; Piñero, A. Assess in order to transform: University teaching assessment through the lens of Sustainability. Enseñanza De Las Ciencias Revista De Investigación y Experiencias Didácticas 2017, 35, 5. [CrossRef]

36. Aznar Minguet, P.; Ull, M.A.; Piñero, A.; Martínez-Agut, M.P. La sostenibilidad en la formación universitaria: Desafíos y oportunidades. Educ. XX1 2013, 17, 133-157. [CrossRef]

37. Solis-Espallargas, C.; Valderrama-Hernández, R. La educación para la sostenibilidad en la formación de profesorado. ¿Qué estamos haciendo? Foro Educ. 2015, 13, 165-192. [CrossRef]

38. Flick, U. An Introduction to Qualitative Research, 4th ed.; Sage: London, UK, 2009.

39. Albareda-Tiana, S.; Ruíz-Morales, J.; Azcárate, P.; Valderrama-Hernández, R.; Múñoz, J. El Proyecto EDINSOST: Implementación de los Objetivos de Desarrollo Sostenible a Nivel Universitario. In Universities as Living Labs for Sustainable Development; Springer: Berlin/Heidelberg, Germany, 2019; pp. 193-210.

40. Miller, G.E. The assessment of clinical skills/competence/performance. Acad. Med. 1990, 65, S63-S67. [CrossRef]

41. Villasante, T.R.; Montañés, M.; Martí, J. La Investigación Social Participativa. Construyendo Ciudadanía 1; El Viejo Topo. Cit. en Villasante, Montañes y Martí, J: Madrid, Spain, 2000; p. 67.

42. Lozano, R.; Merrill, M.; Sammalisto, K.; Ceulemans, K.; Lozano, F.J. Connecting Competences and Pedagogical Approaches for Sustainable Development in Higher Education: A Literature Review and Framework Proposal. Sustaintability 2017, 9, 1889. [CrossRef]

43. Murga-Menoyo, M.A. Competencias para el desarrollo sostenible: Las capacidades, actitudes y valores meta de la educación en el marco de la Agenda global post-2015. Foro de Educación 2015, 13, 55-83. [CrossRef]

(C) 2019 by the authors. Licensee MDPI, Basel, Switzerland. This article is an open access article distributed under the terms and conditions of the Creative Commons Attribution (CC BY) license (http://creativecommons.org/licenses/by/4.0/). 